\title{
Community participation based on social capital to enhance tourist visit at Lake Toba Parapat North Sumatera
}

\author{
Erika Revida ${ }^{1 *}$ and Sukarman Purba ${ }^{2}$ \\ ${ }^{1}$ Public Administration Departement, Universitas Sumatera Utara, Medan, Indonesia \\ ${ }^{2}$ Education Managenent, Universitas Negeri Medan, Medan, Indonesia
}

\begin{abstract}
The The purpose of this research was to analyze the participation of community based on social capital to enhance tourist visit at Lake Toba Parapat North Sumatera. The study utililized both qualitative and quantitative methods. 80 respondents (head of family) were interviewed at Lake Toba Parapat North Sumatera. Thte analysis technique of data used quantitative research used descriptive statistics, and multiple regression analysis, whereas qualitative research started from the data organization, reduction and interpretation of data and took conclusion on the results of research. The results of the research showed that the hypothesis of research that there was a positive and significant influence between social capital on the community participation to enhance tourist visits in Lake Toba Parapat North Sumatra was accepted. Participation of community based on social capital to enhance tourist visit was in moderat and it can be further improved by social activities including communication, information sharing and education on the importance of community participation based on social capital such as cohesiveness, altruism, networking, coorperation, unselfish feeling, and trust.
\end{abstract}

\section{Background}

Tourism development in various region including Lake Toba Parapat North Sumatera is an important and urgent sector, especially in the era of decentralization now on. Tourism is a journey undertaken by one or groups of people from one place to another in other to enjoy the beauty of nature with the aim of seeking pleasure. Tourism development is a variety of tourism activities undertaken by community, private and government supported by tourism facilities and services to enhance the number of tourist visits both domestic and foreign countries. Tourism not only enhance state/central revenue but also enhance community income and local revenue. Therefore, the participation of all elements include government, private and community around tourist site become a very important strategic issue to enhance the tourist visit. Therefore the participation of community based on social capital to enhance tourist visit will be a good concept in Lake Toba Parapat North Sumatera.

\footnotetext{
*Correspondent Author: erikarevida@yahoo.com
} 
According to Law of Tourism number 10 of 2009 [1], the destination of tourism development are to promote economic growth, prosperity of the people, eradicate poverty, overcome unemployment, conserve nature, environment, and resources, promote culture, elevate the image of the nation, nurture the love of the country, strengthen the identity and unity of the nation, and strengthen friendship among nations. It means that the development of tourism conducted with the participation of community-based social capital is an absolute requirement at the Lake Toba Parapat North Sumatera.

But, even central and the local government had already undertaken a various tourism development programs to enhance tourist visit, but in fact that up to now at tourism sector especially Lake Toba Parapat North Sumatra did not have a significant results to increase tourist visit. Decreasing number of tourist visits both domestic and foreign countries in North Sumatera since the last 3 (three) years can seen from the following table.

Table 1 Number of Tourist Visit to Lake Toba North Sumatera 2014-2017

\begin{tabular}{|c|c|c|}
\hline No & Tourist Visit (Year) & Total (people) \\
\hline 1 & 2014 & 270.837 \\
\hline 2 & 2015 & 229.288 \\
\hline 3 & 2016 & 233.643 \\
\hline 4 & 2017 & 167.037 \\
\hline & Total & 900.805 \\
\hline
\end{tabular}

Source : Badan Pusat Statistik Sumatera Utara, 2017[2]

The development of the tourism sector to enhance tourist visit is not only a mere of government affair alone, but also required the participation of private and the community especially around of tourist site. This was the reason why this research conducted by taking the title "Participation of Community Based on Social Capital to Enhance Tourism Visit In Lake Toba Parapat North Sumatera".

\section{Literature Review}

Participation of community is a role of community in every stage of activities in development including the tourism development starting from the process of identifying the problems and potentials in the community, the selection and decision-making on alternative solutions to handle problems, implementation of the program and the effort to solve the problem, and also evaluating the programs[3].

While social capital define as a set of values and norms that are recognized and shared by the local community and be used as guidelines in behaving in community everyday and implemented by a good cooperation in the community [4] stated that the components of social capital were trust, cohesiveness, altruism, unselfish feeling, cooperation, and network. Thus, the participation of community based on social capital is the active participation of community that is driven by social capital such as trust, cohesiveness, altruism, unselfish feeling, cooperation, and networks.

In this research the meaning of participation of community based on social capital to enhance tourist visits is the community involvement by giving contribution of thoughts, energy, time, funds, and facilities based on trust, cohesiveness, altruism, unselfish feeling, cooperation, and networks to enhance tourist visit at Lake Toba Parapat North Sumatra. 


\section{Research Method}

The study employed both quantitative and qualitative methods [5]. The respondents consist of 80 local community people who lived in Lake Toba Parapat North Sumatera. The research informant were bureaucratic apparatus in head of distric, head and village apparatus around Lake Toba Parapat North Sumatera.

Data were collected from literatures, questionnaire, observations and interviews. The data were then analyzed by using descriptive statistic, and simple regression analysis. Qualitative research methods were done from data organization, reduction, and interpretation of data and took conclusiona of the result [6].

\section{Result and Discussion}

\subsection{Participation of Community Based on Social Capital to Enhance Tourist Visit at Lake Toba Parapat North Sumatera}

The participation of community based on social capital to enhance tourist visit at Lake Toba Parapat North Sumatera was the active involvement of community by giving by giving contribution of thoughts, energy, time, funds, and facilities based on the trust, cohesiveness, altruism, unselfish feeling, mutual cooperation, and network among community, community with government, and the public with the private sector to enhance tourist visit at Lake Toba Parapat North Sumatera. The result of study id shown in table 2.

Table 2 Participation of community based on social capital to enhance tourist visit at Lake Toba Parapat North Sumatera, 2017.

\begin{tabular}{|c|c|c|c|c|c|c|}
\hline \multirow[t]{2}{*}{ No } & \multirow[t]{2}{*}{ Instrument } & \multicolumn{5}{|c|}{ Responden Answers } \\
\hline & & SA & A & $\mathrm{S}$ & $\mathrm{N}$ & VN \\
\hline 1 & $\begin{array}{l}\text { The trust of government can increase } \\
\text { your participation to enhance tourist } \\
\text { visits in Lake Toba Parapat North } \\
\text { Sumatera }\end{array}$ & $\begin{array}{c}10 \\
12,50 \%\end{array}$ & $\begin{array}{c}20 \\
25 \%\end{array}$ & $\begin{array}{c}30 \\
37,50 \%\end{array}$ & $\begin{array}{c}20 \\
25 \%\end{array}$ & - \\
\hline 2 & $\begin{array}{l}\text { The trust of community can increase } \\
\text { your participation to enhance tourist } \\
\text { visit in Lake Toba Parapat North } \\
\text { Sumatera }\end{array}$ & $\begin{array}{c}7 \\
8,75 \%\end{array}$ & $\begin{array}{c}20 \\
25 \%\end{array}$ & $\begin{array}{c}29 \\
36,25 \%\end{array}$ & $\begin{array}{c}20 \\
25 \%\end{array}$ & $\begin{array}{c}4 \\
5 \%\end{array}$ \\
\hline 3 & $\begin{array}{l}\text { The trust of private sector can increase } \\
\text { your participation to enhance tourist } \\
\text { visits in Lake Toba Parapat North } \\
\text { Sumatera? }\end{array}$ & $\begin{array}{c}8 \\
10 \%\end{array}$ & $\begin{array}{c}22 \\
27,5 \%\end{array}$ & $\begin{array}{c}32 \\
40 \%\end{array}$ & $\begin{array}{c}18 \\
22,50 \%\end{array}$ & - \\
\hline 4 & $\begin{array}{l}\text { Do you have any confidence that the } \\
\text { government will enhance tourist visit } \\
\text { in Lake Toba Parapat North Sumatra? }\end{array}$ & $\begin{array}{c}10 \\
12,50 \%\end{array}$ & $\begin{array}{c}19 \\
23,75 \%\end{array}$ & $\begin{array}{c}36 \\
45 \%\end{array}$ & $\begin{array}{c}15 \\
18,75 \%\end{array}$ & - \\
\hline 5 & $\begin{array}{l}\text { Do you have any confidence that the } \\
\text { local people will enhance tourist visit } \\
\text { in Lake Toba Parapat North Sumatera? }\end{array}$ & $\begin{array}{c}15 \\
18,75 \%\end{array}$ & $\begin{array}{c}20 \\
25 \%\end{array}$ & $\begin{array}{c}33 \\
41,25 \%\end{array}$ & $\begin{array}{c}12 \\
15 \%\end{array}$ & - \\
\hline 6 & $\begin{array}{l}\text { Do you have a belief that private sector } \\
\text { will enhance tourist visit in Lake Toba } \\
\text { Parapat North Sumatera? }\end{array}$ & $\begin{array}{c}6 \\
7,50 \%\end{array}$ & $\begin{array}{c}30 \\
37,50 \%\end{array}$ & $\begin{array}{c}27 \\
33,75 \%\end{array}$ & $\begin{array}{c}17 \\
21,25 \%\end{array}$ & - \\
\hline 7 & $\begin{array}{l}\text { Is the cohesiveness with the } \\
\text { government can increase your } \\
\text { participation to enhance tourist visit in } \\
\text { Lake Toba Sumatera Utara? }\end{array}$ & $\begin{array}{c}10 \\
12,50 \%\end{array}$ & $\begin{array}{c}25 \\
31,25 \%\end{array}$ & $\begin{array}{c}29 \\
36,25 \%\end{array}$ & $\begin{array}{c}16 \\
20 \%\end{array}$ & - \\
\hline 8 & Is the cohesiveness with the private & 12 & 31 & 30 & 7 & - \\
\hline
\end{tabular}




\begin{tabular}{|c|c|c|c|c|c|c|}
\hline & $\begin{array}{l}\text { sector can increase your participation } \\
\text { to enhance tourist visits in Lake Toba } \\
\text { North Sumatera? }\end{array}$ & $15 \%$ & $38,75 \%$ & $37,50 \%$ & $8,75 \%$ & \\
\hline 9 & $\begin{array}{l}\text { Does the cohesiveness with local } \\
\text { people increase your participation to } \\
\text { enhance tourist visits in Lake Toba } \\
\text { North Sumatera? }\end{array}$ & $\begin{array}{c}7 \\
8,75 \%\end{array}$ & $\begin{array}{c}30 \\
37,50 \%\end{array}$ & $\begin{array}{c}28 \\
35 \%\end{array}$ & $\begin{array}{c}15 \\
18,75 \%\end{array}$ & - \\
\hline 10 & $\begin{array}{l}\text { The attention of tourists (altruism) can } \\
\text { enhance tourist visits in Lake Toba } \\
\text { Parapat North Sumatera }\end{array}$ & $\begin{array}{c}5 \\
6,25 \%\end{array}$ & $\begin{array}{c}35 \\
43,75 \%\end{array}$ & $\begin{array}{c}30 \\
37,50 \%\end{array}$ & $\begin{array}{c}10 \\
12,50 \%\end{array}$ & - \\
\hline 11 & $\begin{array}{l}\text { The attention of the facilities of } \\
\text { tourism such as infrastructure and so } \\
\text { on can enhance tourist visit in Lake } \\
\text { Toba Parapat North Sumatera }\end{array}$ & $\begin{array}{c}11 \\
13,75 \%\end{array}$ & $\begin{array}{c}20 \\
25 \%\end{array}$ & $\begin{array}{c}29 \\
50 \%\end{array}$ & $\begin{array}{c}20 \\
25 \%\end{array}$ & - \\
\hline 12 & $\begin{array}{l}\text { Did you have any attention to tourists } \\
\text { who come to Lake Toba Parapat North } \\
\text { Sumatera? }\end{array}$ & $\begin{array}{c}10 \\
12,5 \%\end{array}$ & $\begin{array}{c}28 \\
41,25 \%\end{array}$ & $\begin{array}{c}33 \\
41,25 \%\end{array}$ & $\begin{array}{c}12 \\
15 \%\end{array}$ & - \\
\hline 13 & $\begin{array}{l}\text { Did you have any attention of tourist } \\
\text { facilities/infrastructure in Lake Toba } \\
\text { Parapat North Sumatera? }\end{array}$ & $\begin{array}{c}7 \\
8,75 \%\end{array}$ & $\begin{array}{c}20 \\
25 \%\end{array}$ & $\begin{array}{c}29 \\
36,25 \%\end{array}$ & $\begin{array}{c}20 \\
25 \%\end{array}$ & $\begin{array}{c}4 \\
5 \%\end{array}$ \\
\hline 14 & $\begin{array}{l}\text { Did you do a prioritize the interests of } \\
\text { tourists rather than your own in Lake } \\
\text { Toba Parapat North Sumatera? }\end{array}$ & $\begin{array}{c}8 \\
10 \%\end{array}$ & $\begin{array}{c}32 \\
40 \%\end{array}$ & $\begin{array}{c}22 \\
27,5 \%\end{array}$ & $\begin{array}{c}18 \\
22,50 \%\end{array}$ & - \\
\hline 15 & $\begin{array}{l}\text { Did you pay attention to the needs or } \\
\text { desires of tourists to enhance tourist } \\
\text { visit in Lake Toba Parapat North } \\
\text { Sumatera? }\end{array}$ & $\begin{array}{c}10 \\
12,50 \%\end{array}$ & $\begin{array}{c}10 \\
12,50 \%\end{array}$ & $\begin{array}{c}50 \\
75 \%\end{array}$ & $\begin{array}{c}10 \\
12,50 \%\end{array}$ & - \\
\hline 16 & $\begin{array}{l}\text { Did you work without expecting a } \\
\text { rewards to enhance tourist visits in } \\
\text { Lake Toba Parapat North Sumatera? }\end{array}$ & $\begin{array}{c}12 \\
15 \%\end{array}$ & $\begin{array}{c}18 \\
18,75 \%\end{array}$ & $\begin{array}{c}32 \\
40 \%\end{array}$ & $\begin{array}{c}18 \\
18,75 \%\end{array}$ & - \\
\hline 17 & $\begin{array}{l}\text { Did you do prioritize mutual needs to } \\
\text { enhance tourist visit in Lake Toba } \\
\text { North Sumatera? }\end{array}$ & $\begin{array}{c}10 \\
12,50 \%\end{array}$ & $\begin{array}{c}20 \\
25 \%\end{array}$ & $\begin{array}{c}32 \\
40 \%\end{array}$ & $\begin{array}{c}18 \\
22,50 \%\end{array}$ & - \\
\hline 18 & $\begin{array}{l}\text { Did you do a prioritize to the need of } \\
\text { government to enhance tourist visit in } \\
\text { Lake Toba Parapat North Sumatera? }\end{array}$ & $\begin{array}{c}11 \\
13,75 \%\end{array}$ & $\begin{array}{c}27 \\
33,75 \%\end{array}$ & $\begin{array}{c}28 \\
35 \%\end{array}$ & $\begin{array}{c}14 \\
35 \%\end{array}$ & - \\
\hline 19 & $\begin{array}{l}\text { Did you notice the more urgent needs } \\
\text { of tourist to enhance tourist visit in } \\
\text { Lake Toba Parapat North Sumatera? }\end{array}$ & $\begin{array}{c}9 \\
11,25 \%\end{array}$ & $\begin{array}{c}16 \\
20 \%\end{array}$ & $\begin{array}{c}31 \\
38,75 \%\end{array}$ & $\begin{array}{c}22 \\
27,50 \%\end{array}$ & $\begin{array}{c}2 \\
2,50 \%\end{array}$ \\
\hline 20 & $\begin{array}{l}\text { Do you want to work together with } \\
\text { community to enhance tourist visits in } \\
\text { Lake Toba Parapat North Sumatera? }\end{array}$ & $\begin{array}{c}9 \\
11,25 \%\end{array}$ & $\begin{array}{c}30 \\
37,50 \%\end{array}$ & $\begin{array}{c}30 \\
37,50 \%\end{array}$ & $\begin{array}{c}11 \\
13,75 \%\end{array}$ & - \\
\hline 21 & $\begin{array}{l}\text { Did other communities cooperate to } \\
\text { enhance tourist visits in Lake Toba } \\
\text { Parapat North Sumatera? }\end{array}$ & 8 & $\begin{array}{r}20 \\
\%\end{array}$ & $\begin{array}{c}38 \\
47,50 \%\end{array}$ & $\begin{array}{c}12 \\
15 \%\end{array}$ & - \\
\hline 22 & $\begin{array}{l}\text { Did you have network with } \\
\text { government to enhance tourist visits in } \\
\text { Lake Toba Parapat North Sumatera? }\end{array}$ & $\begin{array}{c}8 \\
10 \%\end{array}$ & $\begin{array}{c}12 \\
15 \%\end{array}$ & $\begin{array}{c}32 \\
40 \%\end{array}$ & $\begin{array}{c}25 \\
31,25 \%\end{array}$ & $\begin{array}{c}3 \\
3,75 \%\end{array}$ \\
\hline 23 & $\begin{array}{l}\text { Did you have networking with the } \\
\text { privat sectors to enhance tourist visits } \\
\text { in Lake Toba Parapat North Sumatera? }\end{array}$ & $\begin{array}{c}10 \\
12,5 \%\end{array}$ & $\begin{array}{c}30 \\
37,5 \%\end{array}$ & $\begin{array}{c}33 \\
41,25 \%\end{array}$ & $\begin{array}{c}7 \\
8.75 \%\end{array}$ & - \\
\hline 24 & $\begin{array}{l}\text { Did you have networking with other } \\
\text { communities to enhance tourist visits } \\
\text { in Lake Toba Parapat North Sumatera? }\end{array}$ & $\begin{array}{c}12 \\
15 \%\end{array}$ & $\begin{array}{c}28 \\
41,25 \%\end{array}$ & $\begin{array}{c}33 \\
41,25 \%\end{array}$ & $\begin{array}{c}10 \\
12,5 \%\end{array}$ & - \\
\hline
\end{tabular}




\begin{tabular}{|c|c|c|c|c|c|c|}
\hline 25 & $\begin{array}{l}\text { Did you urge other community around } \\
\text { the tourist sites to enhance tourist visits } \\
\text { in Lake Toba Parapat North Sumatera? }\end{array}$ & $\begin{array}{c}10 \\
12,5 \%\end{array}$ & $\begin{array}{c}19 \\
23,75 \%\end{array}$ & $\begin{array}{c}35 \\
43,75 \%\end{array}$ & $\begin{array}{c}11 \\
13,75 \%\end{array}$ & $\begin{array}{c}5 \\
6,25 \%\end{array}$ \\
\hline \multicolumn{7}{|c|}{ Note : } \\
\hline SA & : Strongly Agree & & & & & \\
\hline A & : Agree & & & & & \\
\hline S & : Sometimes & & & & & \\
\hline $\mathrm{N}$ & : Never & & & & & \\
\hline VN & : Very Never & & & & & \\
\hline 4.2 & $\begin{array}{l}\text { The Trend Level of Participatio } \\
\text { At Lake Toba Parapat North Su }\end{array}$ & $\begin{array}{l}\text { of } \mathrm{Cc} \\
\text { atera }\end{array}$ & Iunity & Enha & & \\
\hline
\end{tabular}

The trend level of community participation based on social capital to enhance tourist visit at Lake Toba Parapat North Sumatera could be seen in table 3.

Table 3 The trend level of participation of community based on social capital to enhance tourist visit at Lake Toba Parapat North Sumatera, 2017

\begin{tabular}{|c|c|c|c|}
\hline Range & F. Absolute & F. Relative & Category \\
\hline $89-110$ & 20 & $25.00 \%$ & Good \\
\hline $66-88$ & 46 & $57.50 \%$ & Moderate \\
\hline $43-65$ & 14 & $17.50 \%$ & Less \\
\hline $20-42$ & 0 & $0.00 \%$ & Low \\
\hline Total & 80 & $100.00 \%$ & \\
\hline
\end{tabular}

As shown in table 3, it can be said that the trend level of participation of community to enhance tourist visit at Lake Toba Parapat North Sumatera was in moderate category and need to enhance by participation of community based on social capital.

Participation of community to enhance tourist visits can be done in various forms, as an example by developing the potential of local art and culture such as culinary, fashion, cultural performing arts, and so on. The show of potential of local art and culture will bring something uniqueness for tourists and also makes local community proud of them.

\section{Conclusions and Recommendations}

The hypothesis of research stated that there was a positive and significant influence between Social Capital on the Participation of Community to enhance tourist visits in Lake Toba Parapat North Sumatra was accepted. Participation of community based on social capital to enhance tourist visit was in moderat category. From the six indicators of Social Capital, the greatest influence towards Participation of Community to enhance tourist visits was cohesiveness, followed by Altruism, Networking, Coorperation, Unselfish Feeling, and the weekness was Trust

The hypothesis of research stated that there was a positive and significant influence between Social Capital on the Participation of Community to enhance tourist visits in Lake Toba Parapat North Sumatra was accepted, therefore social capital namely cohesiveness, altruism, networking, coorperation, unselfish feeling, and trust need to increase by socialization and role playing. Participation of community based on social capital to enhance tourist visit was in moderat category, therefor need to increase by involving 
community leader, religious leader and educational leader in all situations. From the six indicators of Social Capital, the greatest influence towards Participation of Community to enhance tourist visits was cohesiveness, followed by Altruism, Networking, Coorperation, Unselfish Feeling, and the weekness was Trust. It means that cohesiveness was an important thing to increase among society, leaders and privat sectors by increasing emotional closeness, forming groups that share common goals and have caring leaders.

\section{Acknowledgements}

Finnally, I thank to the honorable : 1. Ministry of Research and Technology and higher education of the Republic of Indonesia who has funded this research. 2. Rector of Universitas Sumatera Utara, Dean of Fakulty of Social and Political Science and Chairman of Public Administration Departement which has given permission to do this research. 3. Head of tourism department simalungun regency and his staff. 4. Respondents and informants of this study who had been willing to provide data needed in this study. Hopefully this article useful to enhance tourist visit at Lake Toba Parapat North Sumatera.

\section{References}

1. Undang-undang Nomor 10 tahun 2009 tentang Kepariwisataan. Jakarta : Sekretariat Negara.

2. Badan Pusat Statistik Sumatera Utara. 2017. Medan : Sekretariat Daerah

3. R.A. Isbandi, Perencanaan Partisipatoris Berbasis Aset Komunitas : Dari Pemikiran Menuju Penerapan, (FISIP UI Press, Jakarta, 2007)

4. F. Fukuyama, Trust : Kebajikan Sosial dan Penciptaan Kemakmuran, (Penerbit Qalam, Yogyakarta, 2007)

5. J.W. Creswell, Research Design. Qualitative \& Quantitative Approaches (Sage Publication, Inc, New York, 2004)

6. L.J. Moleong, Metodologi Penelitian Kualitatif. Edisi Revisi. (Penerbit PT Remaja Rosdakarya, Bandung, 2006) 